\title{
An Open-Label Study of Aripiprazole for Methamphetamine Induced Psychosis
}

\author{
Ahmad Hatim Sulaiman', Jesjeet Singh Gill', Mas Ayu Said ${ }^{2}$, Mohamad Hussain Habil' \\ Nor Zuraida Zainal' ${ }^{1}$ Ng Chong Guan ${ }^{3}$
}

\section{ÖZET:}

Metamfetamine bağlı psikozda aripiprazol: Bir açık çalışma

Amaç: Bu çalışmada metamfetamin bağımlıı̆ı olan hastalardaki psikozun tedavisinde aripiprazol'ün terapötik etkisini ve tolerabilitesini değerlendirmek amaçlanmıştır.

Yöntem: Bu prospektif tek kollu açık çalışma Malaya Üniversitesi Tıp Merkezi'nde [University Malaya Medical Centre (UMMC)] yürütülmüştür. Çalışmaya DSM-IV'e göre metamfetamin bağımlıı̆ı ile birlikte akut psikotik semptomları bulunan hiç tedavi almamış hastalar alındı. Çalışmaya alınan hastalara başlangıçta 5-10 mg, sonraki 2-14 günde esnek dozda (5-15 mg/gün) aripiprazol verildi.

Bulgular: Çalışmaya katılan 49 hastadan 41' i (\%83.7) çalışmayı tamamladı. Başlangıç PANSS toplam puanı ortalaması $79.2 \pm 13.7$ ve CGI-S puanı ortalaması $4.3 \pm 0.5$ idi. Çalışma sonunda PANNS-toplam ve CGI-S puanlarında istatistiksel olarak anlamlı ölçüde azalma gözlendi. Başlangıca göre 14'üncü günde PANSS puanında ortalama 27.6 \pm 21.4 puan $[p<0.05,95 \% \mathrm{Cl}(-34.8,-20.4)]$ ve CGI-S puanında ortalama $2.0 \pm 1.2$ puan $[p<0.05,95 \%$ $\mathrm{Cl}(-2.4,-1.6)]$ saptandı. Çalışma süresince aripiprazol genel olarak iyi tolere edildi. On (\%20.4) hastada yan etki rapor edildi. Hareket ile ilişkili yan etkiler bakımından istatistiksel olarak anlamlı bir farklıık saptanmadı. Sonuç: Bu çalışmada metamfetamin kullanımıyla ilişkili psikotik semptomların aripiprazol tedavisiyle düzeldiği saptandı. Aripiprazol hafif-orta düzeydeki yan etki profili ile genel olarak iyi tolere edildi. Bu bulgular ışığında aripiprazol metamfetamin ile ilişkili psikozun tedavisinde etkili ve güvenli bir tedavi seçeneği olarak düşünülebilir.

Anahtar sözcükler: Metamfetamin bağımlılığı, psikoz, aripiprazol, açık çalışma, güvenlik, etkililik

Klinik Psikofarmakoloji Bülteni 2012;22(2):121-9

\section{ABSTRACT:}

An open-label study of aripiprazole for methamphetamine induced psychosis

Objective: This study aimed to explore the therapeutic effects and tolerability of aripiprazole in the treatment of psychosis among methamphetamine dependent patients.

Methods: This was an open label single arm prospective study conducted at the University Malaya Medical Centre (UMMC). The study subjects included treatment naive patients with a current diagnosis of methamphetamine dependence with co-occurring acute psychotic symptoms based on the Diagnostic and Statistical Manual of Mental Disorders-IV (DSMIV). Eligible patients were treated with an initial dose of 5-10 mg aripiprazole followed by flexible doses (5-15mg/day) from day 2 to 14 .

Results: Out of 49 patients enrolled, 41 patients (83.7\%) completed the study. At baseline the mean PANSS total score was $79.2 \pm 13.7$ and the mean CGI-S score was $4.3 \pm 0.5$. There was a statistically significant decline in the mean PANSS-total and CGI-S scores over the course of the study. The mean reduction was $27.6 \pm 21.4$ point $(p<0.05,95 \% \mathrm{Cl}(-34.8,-20.4))$ from baseline on day 14 for total PANSS score and $2.0 \pm 1.2$ point $(p<0.05,95 \% \mathrm{Cl}(-2.4,-1.6)$ for CGI-S. Aripiprazole was generally well tolerated during the study. Adverse events were reported in 10 (20.4\%) patients. No statistically significant changes were noted with respect to movement-related adverse events.

Conclusions: This study found that aripiprazole improved the psychotic symptoms associated with methamphetamine use. It was generally well tolerated with mild to moderate adverse events. Based on these results aripiprazole might be an effective and safe option for the treatment of methamphetamine induced psychosis.

Key words: Methamphetamine dependence, psychosis, aripiprazole, open label study, safety, efficacy

Bulletin of Clinical Psychopharmacology 2012;22(2):121-9
${ }^{1} \mathrm{M}$ Psych Med, ${ }^{3} \mathrm{M}$ Psych Med, MSc, Department of Psychological Medicine, Faculty of Medicine, University Malaya, Kuala Lumpur, Malaysia ${ }^{2} \mathrm{MPH}$, Department of Social and Preventive Medicine, Faculty of Medicine, University Malaya, Kuala Lumpur, Malaysia

Yazışma Adresi / Address reprint requests to: $\mathrm{Ng}$ Chong Guan, Department of Psychological Medicine, Faculty of Medicine, University Malaya, Lembah Pantai 50603 Kuala Lumpur, Malaysia

Telefon / Phone: +60-379-492-068

Faks / Fax: +60-379-556-477

Elektronik posta adresi / E-mail address: chong_guan1975@yahoo.co.uk

Gönderme tarihi / Date of submission: 11 Aralık 2011 / December 11, 2011

Kabul tarihi / Date of acceptance: 19 Nisan 2012 / April 19, 2012

\section{Bağıntı beyanı:}

A.H.S., J.S.G., M.A.S., M.H.H., N.Z.Z., N.C.G. Yazarlar bu makale ile ilgili olarak herhangi bir çıkar çatışması bildirmemişlerdir.

\section{Declaration of interest:}

A.H.S., J.S.G., M.A.S., M.H.H., N.Z.Z., N.C.G.: The authors reported no conflict of interest related to this article. 


\section{INTRODUCTION}

Methamphetamine (MA) is a psycho-stimulant drug with addictive and long lasting stimulant effects. Because of its wide availability and lower cost, methamphetamine has become one of the most commonly consumed illicit substances, not only locally in Malaysia, but globally as well (1). Acutely, methamphetamine can trigger psychotic symptoms in individuals with no past history of psychosis (2). Accumulated evidence has indicated that chronic use of methamphetamine gradually leads to the development of a psychotic state resembling paranoid schizophrenia (3). It has been reported that methamphetamine dependent users were three times more likely to experience psychotic symptoms than non-regular methamphetamine users (4).

Although methamphetamine induced psychiatric disorders are typically self-limiting, treatment may be required in emergency situations, as well as to prevent recurrence. Recurrence of psychotic symptoms can occur due to the continued use of methamphetamine or other drugs, and also due to psychosocial stressors $(5,6)$. In some cases psychosis may persist and around $5-15 \%$ of methamphetamine users fail to recover completely (7).

To date, there is little empirical evidence on pharmacological treatment options for methamphetamine induced psychosis. Most published data consists of case reports and small open label studies (8). There is currently no approved medication by the Food and Drug Administration (FDA) or the Malaysian Drug Authority for the treatment of methamphetamine induced psychosis.

An early study showed that intramuscular haloperidol administration significantly reduced the symptoms of methamphetamine induced excitement and paranoid ideation within an hour (9). Droperidol was also shown to sedate agitated methamphetamine users significantly faster than lorazepam after intravenous administration (10). Case studies with the newer atypical antipsychotics such as olanzapine (11), risperidone (12) and quetiapine (13) have also revealed possible benefits.

Aripiprazole is an atypical antipsychotic medication indicated for the treatment of schizophrenia and acute manic episodes associated with bipolar 1 disorder. Unlike other atypical antipsychotics (e.g. olanzapine, quetiapine, risperidone) that act as antagonists at D2 dopamine receptors $(14,15)$, aripiprazole appears to mediate its antipsychotic effects primarily by partial agonism at D2 receptors $(16,17,18)$. This partial agonist effect stabilizes dopamine receptors while allowing a modulation of function, rather than blocking them exclusively. Therefore, partial agonists are also known as dopamine system stabilizers, which constitute a new class of antipsychotic agents without leading to apparent motor side effects (19). It is this partial dopamine agonist effect of aripiprazole that has been tested for in reducing cocaine cravings in schizophrenic cocaine-dependent subjects (20). It is hypothesized that aripiprazole acts either through lowering dopamine over-activity, through increasing dopamine under-activity, or through some combination of both.

Aripiprazole has been shown to produce significant improvements in positive and negative symptoms in shortand long-term studies of patients with schizophrenia or schizoaffective disorder (21). Aripiprazole has been shown to have a low risk for extrapyramidal symptoms (EPS) and hyperprolactinemia, a lack of QTc prolongation, and minimal weight gain or sedation (21). Aripiprazole has also been found to be useful in treating psychosis associated with Parkinson's Disease (22), preventing relapse in bipolar 1 disorder (23), and to be an effective and safe adjunctive therapy to standard anti-depressant treatment in patients with major depressive disorder (24). The proven efficacy and safety of aripiprazole in a number of psychiatric disorders provides a rationale for investigating this drug in the treatment of methamphetamine induced psychosis. The aims of this open-label study were to examine the efficacy and tolerability of aripiprazole in the treatment of methamphetamine induced psychosis.

\section{METHODS}

\section{Subjects}

The study subjects were recruited from the inpatient and outpatient clinics of University Malaya Medical Centre (UMMC). Eligible subjects included men and women aged 18 to 60 years old with a current diagnosis of methamphetamine dependence with psychosis. Methamphetamine dependence with psychosis was defined as (1) meeting the Diagnostic and Statistical Manual of Mental Disorders-IV (DSM-IV) diagnosis of methamphetamine dependence based on the MINI International Neuropsychiatric Interview (MINI) (Sheehan et al., 1998b), (2) a score of at least 4 on at least one of the 
following Positive and Negative Symptoms Scale (PANSS) items: P1 - Delusions, P3 - Hallucinatory behaviour, P4 Excitement, P6 - Suspiciousness/persecution, or G9 Unusual thought content, (3) moderate to severe psychosis with a score on the Clinical Global Impression Scale Severity of Illness (CGI-S) $\geq 4$, (4) duration of psychosis for more than 2 weeks, (5) use of methamphetamine at least once a week for the past three months at enrollment and (6) a positive urine screen for methamphetamine. Subjects were also required to be treatment naive and not on any psychotrophics, not dependent on other substances other than nicotine and not suffering from any current intoxification effects of methamphetamine that could interfere with the informed consent process or with compliance with study procedures. Women of childbearing capacity were required to use an appropriate method of birth control.

Suicidal or homicidal subjects were excluded, along with those having serious medical illnesses, known hypersensitivity or allergy to aripiprazole, documented history of having other mental illness that required treatment with antipsychotics, unstable medical conditions and females who were positive on a urine pregnancy test or lactating.

\section{Design}

This was a 14-day open-label, prospective study that examined the safety and tolerability of aripiprazole for the treatment of methamphetamine dependence with psychosis. The study ran from September, 2008 through December, 2010.

\section{Measures}

MINI (25) was used to diagnose methamphetamine dependence and the Amphetamine Withdrawal Questionnaire (AWQ) (26) was utilized for the evaluation of amphetamine withdrawal symptoms. The Brief Substance Craving Scale (BSCS) (27) was used to assess methamphetamine cravings in 3 dimensions: intensity, length, and frequency. The Positive and Negative Symptoms Scale (PANSS) (28) was used to measure psychotic symptom severity. Extrapyramidal symptoms were assessed using the Abnormal Involuntary Movement Scale (AIMS) (29) for tardive dyskinesia, the Barnes
Akathasia Scale (BARS) (30) for drug-induced akathisia and the Simpson Angus Scale (SAS) (31) for antipsychotic induced Parkinsonism. The Clinical Global Impression Scale - Severity of Illness (CGI-S) was used to rate the severity of the patient's illness. Anxiety and depression were measured using the Hospital Anxiety Depression Scale (HADS) (32). A structured questionnaire was used to obtain the patient baseline characteristics, including demographic data, history of methamphetamine use and past medical and surgical history.

\section{Procedures}

The study was approved by the Medical Ethics Committee, University Malaya Medical Centre. Informed consent was obtained from all subjects prior to performing any study procedures. Based on tolerability, oral aripiprazole was started at $5-10 \mathrm{mg} /$ day once daily for 14 days. From Day 2 to Day 14, the dose of aripiprazole could be adjusted to $5 \mathrm{mg} /$ day, $10 \mathrm{mg} /$ day, or $15 \mathrm{mg} /$ day at the investigator's discretion based on the subject's clinical response and tolerability. The investigator could reduce aripiprazole from $10 \mathrm{mg} /$ day to $5 \mathrm{mg} /$ day. Upward titration following a dose reduction was allowed during the trial. Lorazepam was allowed to be administered to treat agitation and anxiety, up to $6 \mathrm{mg} /$ day, but not allowed in the morning prior to scheduled assessments. Zolpidem tartrate (up $10 \mathrm{mg} /$ day) was permitted to treat sleep disturbance throughout the study; all other sleep medications were prohibited. Antidepressant (SNRIs/ SSRIs) was also allowed. Anticholinergics were available to treat emergent EPS but prophylactic use was not permitted. The introduction of other antipsychotic or psychoactive drugs during the study was prohibited, and these drugs must have been discontinued at least 1 week before Day 1. Use of drugs that induce or inhibit hepatic cytochrome 3A4 enzymes was also not permitted from 14 days prior to Day 1 until the end of the treatment period. Depot and long-lasting antipsychotics must have been stopped within at least two and preferably three dosing intervals prior to Day 1 and were prohibited during the treatment period. Subjects were evaluated on day 1, 4, 7, and 14 with the PANSS, CGI-S, AWQ, BSCA, AIMS, BAS and SAS scales. The HADS was conducted only on day 1 and 14. Efficacy analyses were based on the intention-to-treat (ITT) population. 


\section{Data Analysis}

Data analysis was carried out by using the Statistical Package for the Social Sciences (SPSS, 16.0; SPSS Inc. Chicago, III). Descriptive statistics were used to summarize demographic variables, past medical and surgical history, history of drug use and adverse events. Nominal independent variables were described in the form of frequencies and percentages. Continuous independent variables were summarized and described as means, standard deviations, and medians. The paired t-test or Wilcoxon signed rank test was used to examine changes in the PANSS and its subscales, CGI-S, AWQ, BSCS, BARS, SAS, and AIMS scores, by pairing scores at i) baseline before initiating aripiprazole and those at day 4 , ii) baseline before initiating aripiprazole and those at day 7 , and iii)

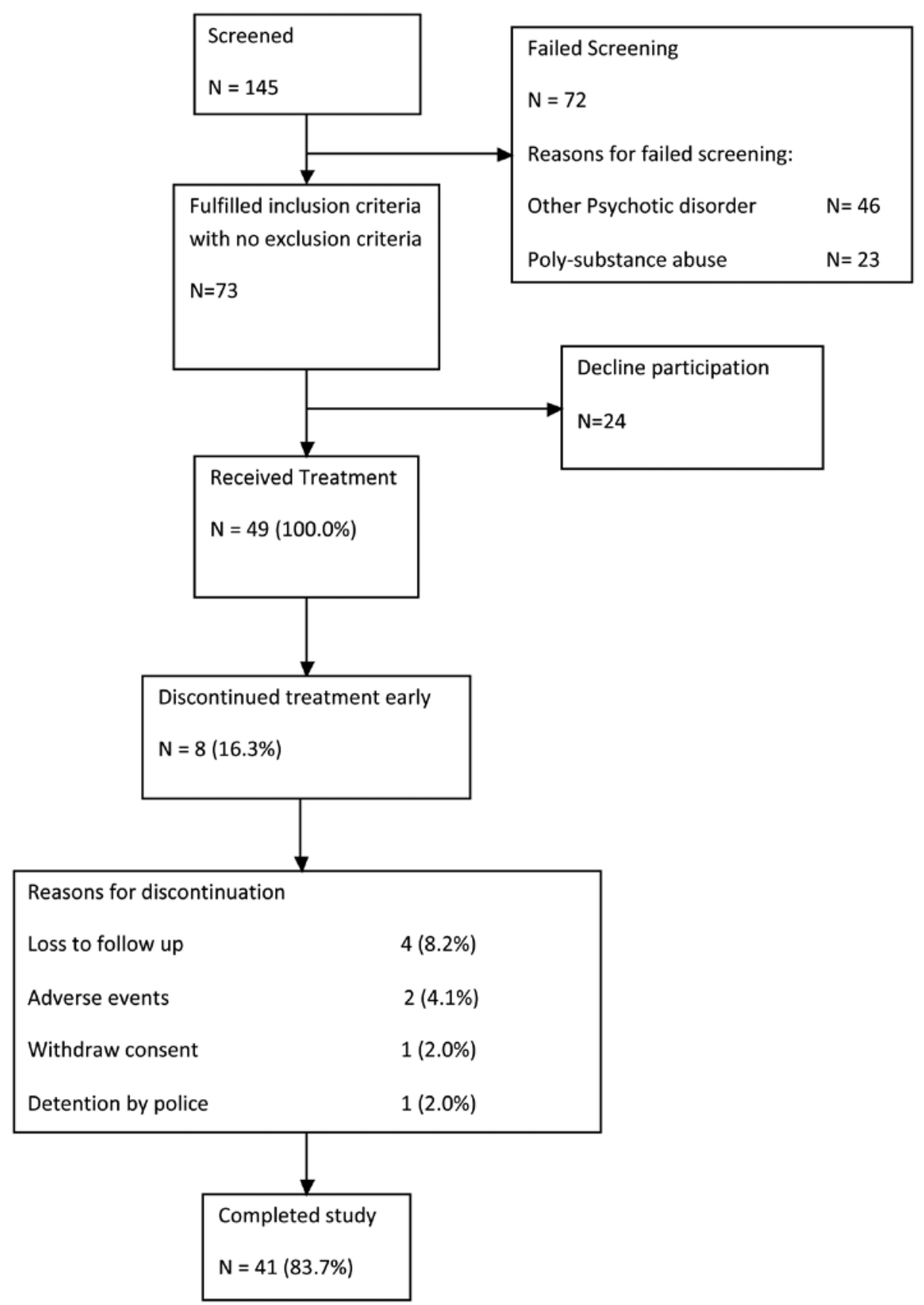

Figure 1: Disposition of patients for aripiprazole treatment in methamphetamine induced psychosis 
baseline before initiating aripiprazole and those at day 14 . The paired t-test using the results of the HADS rating scale was conducted between the baseline measurement before initiating aripiprazole and that at day 14 .

\section{RESULTS}

In total, 145 patients were screened but only 49 eligible subjects agreed to participate and proceeded to receive the study medication. Out of the 49 patients receiving the study medication, $8(16.3 \%)$ subjects discontinued early as illustrated in Figure 1. Socio-demographic characteristics and drug history of the subjects are shown in Table 1. Tables 2 and 3 summarize the measurements of the PANSS, HADS, BSCS, AWQ, BARS, SAS, and AIMS.

The mean dose of aripiprazole was $7.0 \pm 2.9 \mathrm{mg}$ on day

\section{Table 1: Socio-demographic and drug history of the subjects}

\begin{tabular}{|c|c|}
\hline Demographic characteristics & $\mathrm{N}=49$ \\
\hline \multicolumn{2}{|l|}{ Sex, $\mathbf{n}(\%)$} \\
\hline Male & $46(93.9)$ \\
\hline Female & $3(6.1)$ \\
\hline Age, mean years (SD) & $34.2(8.4)$ \\
\hline \multicolumn{2}{|l|}{ Race, n (\%) } \\
\hline Malay & $30(61.2)$ \\
\hline Chinese & $12(24.5)$ \\
\hline Indian & $7(14.3)$ \\
\hline \multicolumn{2}{|l|}{ Marital Status, n (\%) } \\
\hline Married & $19(38.8)$ \\
\hline Single & $24(48.9)$ \\
\hline Divorced & $6(12.3)$ \\
\hline \multicolumn{2}{|l|}{ Education Level, n (\%) } \\
\hline Tertiary & $9(18.4)$ \\
\hline Secondary & $37(75.5)$ \\
\hline Primary & $3(6.1)$ \\
\hline \multicolumn{2}{|l|}{ Employment Pattern, n (\%) } \\
\hline Full Time Job & $38(77.6)$ \\
\hline Part Time Job & $1(2.0)$ \\
\hline Student & $3(6.1)$ \\
\hline Unemployed & $7(14.3)$ \\
\hline Duration of Employment, mean years (SD) & $43.6(51.4)$ \\
\hline Income, mean Ringgit Malaysia (SD) & $3,310.0(4,079.3)$ \\
\hline \multicolumn{2}{|l|}{ Methamphetamine Use History } \\
\hline Onset Age, mean years (SD) & $29.0(9.0)$ \\
\hline Duration Used, mean years (SD) & $5.6(4.4)$ \\
\hline \multicolumn{2}{|l|}{ Amount Used Monthly, mean } \\
\hline Ringgit Malaysia (SD) & $1,386.1(1,846.8)$ \\
\hline \multicolumn{2}{|l|}{ Route of Use, n (\%) } \\
\hline Oral & $5(10.2)$ \\
\hline Nasal & $14(28.6)$ \\
\hline Smoking & $22(61.2)$ \\
\hline
\end{tabular}

$1,7.2 \pm 3.3 \mathrm{mg}$ on day $4,9.2 \pm 3.1 \mathrm{mg}$ on day 7 and $9.4 \pm 3.6$ $\mathrm{mg}$ on day 14 . None of the patients received medication prior to the study and all were neuroleptic naïve. A total of $13(26.5 \%)$ patients received concomitant therapies during the study. Lorazepam was given to 9 (18.4\%) subjects, 4 for akathisia, 3 for agitation, and 2 for insomnia. Zolpidem for insomnia was given to 2 patients $(4.1 \%)$ and other 2 patients $(4.1 \%)$ were given escitalopram for depression.

\section{Efficacy Measurements}

The primary efficacy measurement was the change from baseline in PANSS-Total score to the end of treatment (day 14) where baseline was defined as the day the subject first received the study medication (day 1). Other primary variables included change from baseline in the PANSS positive subscales, PANSS negative subscales, PANSS general psychopathology subscales, and CGI-S to the end of treatment (day 14). The results showed that there was a steady decline in the mean PANSS-Total score over the course of the study, with a mean reduction of $27.6 \pm 21.4$ points ( $\mathrm{p}<0.05,95 \% \mathrm{CI}(-34.8,-20.4)$ from baseline to day 14 (Table 2), thus indicating a statistically significant improvement in patients after receiving aripiprazole. For the CGI scale there was also a significant decline with a mean reduction of $2.0 \pm 1.2$ points $(\mathrm{p}<0.05,95 \% \mathrm{CI}-2.4$, -1.6) from baseline to day 14. Similar statistically significant reductions were also seen in all the PANSS subscale scores from baseline to day 14. Statistically significant improvement was also noted in PANSS-Total, all PANSS subscales and CGI-S scores from baseline to day 4 and at day 7 (Table 2).

The secondary efficacy measures were change from baseline in the AWQ score, BSCS score and HADS score. The results showed that there was a statistically significant decline in the mean AWQ score over the course of the study, with a mean reduction of $-8.5 \pm 9.6$ points $(\mathrm{p}<0.05$, $95 \%$ CI $(-11.8,-5.2)$ from baseline to day 14 (Table 2). For the BSCS scale, the mean reduction was $2.8 \pm 3.8$ points $(\mathrm{p}<0.05,95 \%$ CI $-4.0,-1.5)$ from baseline to day 14 , thus indicating a statistically significant improvement in patients after receiving aripiprazole. The HADS anxiety subscales (Table 2) showed a statistically significant improvement with a mean reduction of $3.9 \pm 4.8$ points $(\mathrm{p}<0.05,95 \%$ CI -5.6, -2.4). Similarly, the HADS depression subscales showed a statistically significant improvement with a mean 


\begin{tabular}{|c|c|c|c|c|c|c|c|}
\hline Variables & Baseline & Day 4 & P value* & Day 7 & P value* & Day 14 & P value* \\
\hline $\begin{array}{l}\text { PANSS Total } \\
\text { Mean (SD) } \\
\text { Median (min, max) }\end{array}$ & $\begin{array}{l}79.2(13.7) \\
79(62,109)\end{array}$ & $\begin{array}{l}71.7 \pm 12.3 \\
72(36,98)\end{array}$ & $<0.01$ & $\begin{array}{l}61.7 \pm 11.9 \\
62(34,85)\end{array}$ & $<0.01$ & $\begin{array}{l}51.6 \pm 14.7 \\
52(30,85)\end{array}$ & $<0.01$ \\
\hline $\begin{array}{l}\text { PANSS - P } \\
\text { Mean (SD) } \\
\text { Median (min, max) }\end{array}$ & $\begin{array}{c}21.7 \pm 5.2 \\
21(12,34)\end{array}$ & $\begin{array}{c}19.0 \pm 4.1 \\
19(10,33)\end{array}$ & 0.03 & $\begin{array}{l}15.7 \pm 3.8 \\
15(8,24)\end{array}$ & $<0.01$ & $\begin{array}{c}12.3 \pm 4.4 \\
12(7,22)\end{array}$ & $<0.01$ \\
\hline $\begin{array}{l}\text { PANSS - N } \\
\text { Mean (SD) } \\
\text { Median (min, max) }\end{array}$ & $\begin{array}{c}16.8 \pm 3.6 \\
16(10,25)\end{array}$ & $\begin{array}{c}15.5 \pm 3.6 \\
16(8,25)\end{array}$ & $<0.01$ & $\begin{array}{c}13.5 \pm 3.6 \\
13(7,21)\end{array}$ & $<0.01$ & $\begin{array}{c}11.2 \pm 3.3 \\
11(7,22)\end{array}$ & $<0.01$ \\
\hline $\begin{array}{l}\text { PANSS - G } \\
\text { Mean (SD) } \\
\text { Median (min, max) }\end{array}$ & $\begin{array}{c}40.6 \pm 7.2 \\
40(30,60)\end{array}$ & $\begin{array}{c}37.2 \pm 6.7 \\
37(18,49)\end{array}$ & 0.02 & $\begin{array}{c}32.5 \pm 6.2 \\
32(19,45)\end{array}$ & $<0.01$ & $\begin{array}{c}27.8 \pm 7.7 \\
28(16,45)\end{array}$ & $<0.01$ \\
\hline $\begin{array}{l}\text { CGI-S } \\
\text { Median } \\
\text { (interquartile range) }\end{array}$ & $\begin{array}{c}4.0 \\
(4.0-5.0)\end{array}$ & $\begin{array}{c}4.0 \\
(4.0-4.0)\end{array}$ & $<0.01 \#$ & $\begin{array}{c}3.0 \\
(2.5-3.5)\end{array}$ & $<0.01 \#$ & $\begin{array}{c}1.0 \\
(2.0-3.0)\end{array}$ & $<0.01 \#$ \\
\hline $\begin{array}{l}\text { AWQ } \\
\qquad \text { Median } \\
\quad \text { (interquartile range) }\end{array}$ & $\begin{array}{c}18.0 \\
(13.0-23.0)\end{array}$ & $\begin{array}{c}17.0 \\
(10.0-21.0)\end{array}$ & $0.01 \#$ & $\begin{array}{c}12.0 \\
(5.0-17.0)\end{array}$ & $<0.01$ & $\begin{array}{c}8.0 \\
(0,14.5)\end{array}$ & $<0.01$ \\
\hline $\begin{array}{l}\text { BSCS } \\
\quad \text { Median } \\
\quad \text { (interquartile range) }\end{array}$ & $\begin{array}{c}8.0 \\
(2.5-9.0)\end{array}$ & $\begin{array}{c}6.0 \\
(0-9.0)\end{array}$ & $0.02 \#$ & $\begin{array}{c}5.0 \\
(0.0-7.5)\end{array}$ & $<0.01 \#$ & $\begin{array}{c}4 \\
(0.0-6.0)\end{array}$ & $0.01 \#$ \\
\hline $\begin{array}{l}\text { HADS - Depression } \\
\text { Mean (SD) } \\
\text { Median (min, max) }\end{array}$ & $\begin{array}{l}8.1(5.0) \\
8(0,17)\end{array}$ & - & & - & & $\begin{array}{c}4.6(4.5) \\
4(0,16)\end{array}$ & $<0.01$ \\
\hline $\begin{array}{l}\text { HADS - Anxiety } \\
\text { Mean (SD) } \\
\text { Median (min, max) }\end{array}$ & $\begin{array}{l}8.8(4.9) \\
9(0,17)\end{array}$ & - & & $\begin{array}{l}- \\
-\end{array}$ & & $\begin{array}{l}3.9(4.8) \\
4(0,16)\end{array}$ & $<0.01$ \\
\hline
\end{tabular}

$\mathrm{P}<0.001$ for all comparisons (day 4, 7 and 14) with baseline, PANSS= Positive and Negative Symptoms Scale

PANSS-P= Positive and Negative Symptoms Scale - Positive subscale, PANSS-N= Positive and Negative Symptoms Scale - Negative subscale

PANSS-G= Positive and Negative Symptoms Scale - General psychopathology subscale, CGI-S= Clinical Global Impression Scale - Severity of IIIness

AWQ= Amphetamine Withdrawal Questionnaire, BSCS= Brief Substance Craving Scale, HADS= Hospital Anxiety Depression Scale

*changes from baseline, \# Wilcoxon signed rank test

\section{Table 3: Treatment emergent adverse events during the study}

All Subjects $(\mathrm{N}=49$ )

Study exposure, mean ( $\min , \max )$ days

$11.7(4,14)$

Number of patients experienced $A E, n(\%)$

$10(20.4 \%)$

ADVERSE EVENT, $\mathbf{n}(\%)$

$15(30.6 \%)$

$4(8.1 \%)$

$4(8.1 \%)$

$3(6.1 \%)$

$2(4.1 \%)$

$2(4.1 \%)$

reduction of $3.5 \pm 5.5$ points $(\mathrm{p}<0.05,95 \%$ CI $-5.4,-1.7)$. Statistically significant reductions in mean scores were also noted for the AWQ and BSCS scales from baseline to day 4 and to day 7 (Table 2).

\section{Safety and Tolerability}

Adverse events (AEs) were reported in 10 (20.4\%) patients during the 14 day study period (Table 4). Most AEs were mild to moderate in intensity. Akathisia was rated as moderate in 2 patients and mild in 2 other patients. Insomnia was rated as mild in all 4 patients. Agitation was rated as mild in all 3 patients. Sedation and depression were all rated as moderate. Both akathisia and insomnia were judged by the investigator to be associated with the study medication. Akathisia did cause 2 patients to discontinue from the study. There were no serious adverse events during the study period and there were no significant changes in BARS, SAS or AIMS scores between baseline and days 4,7 , and 14 (Table 4). 
Table 4: Changes in safety variables

\begin{tabular}{|c|c|c|c|c|c|c|c|}
\hline Variables & Baseline & Day 4 & $\begin{array}{l}\text { p value* } \\
(95 \% \mathrm{CI})\end{array}$ & Day 7 & $\begin{array}{l}\text { p value* } \\
(95 \% \mathrm{CI})\end{array}$ & Day 14 & $\begin{array}{l}\text { p value* } \\
(95 \% \mathrm{Cl})\end{array}$ \\
\hline \multicolumn{8}{|l|}{ BARS } \\
\hline Mean (SD) & $0.7(0.5)$ & $0.2(0.8)$ & 0.73 & $0.3(1.2)$ & 0.37 & $0.7(2.1)$ & 0.16 \\
\hline Median (min, $\max$ ) & $0(0,3)$ & $0(0,5)$ & $(-0.38,0.27)$ & $0(0,5)$ & $(-0.61,0.23)$ & $0(0,8)$ & $(-1.1,0.20)$ \\
\hline SAS & 0 & 0 & - & 0 & - & 0 & - \\
\hline AIMS & 0 & 0 & - & 0 & - & 0 & - \\
\hline
\end{tabular}

P > 0.05 for all comparison (day 4, 7 and 14) with baseline, BARS= Barnes Akathisia Scale, SAS= Simpson Angus Scale, AIMS= Abnormal Involuntary Movement Scale ${ }^{*}$ changes from baseline using Wilcoxon signed rank test

\section{DISCUSSION}

This is the first study in Malaysia to investigate the safety and potential efficacy of aripiprazole in treating individuals with methamphetamine induced psychosis. While the number of patients included in the study was small (49 patients), the patients were reasonably homogenous in the following: i) all patients had methamphetamine induced psychosis, without any history of other psychotic disorders, and ii) no patients had prior exposure to any antipsychotics (neuroleptic naive). However, it should be noted that the subjects in the present study do not represent the typical population of methamphetamine abusers, including habitual users. Thus, the present study has a methodological limitation, where only methamphetamine dependent subjects with psychotic symptoms were examined.

Our subjects exhibited moderate to severe psychotic symptoms at baseline. However, following 2 weeks of aripiprazole treatment, statistically and clinically significant reductions across the assessment instruments used in this study were noted. The reduction in symptoms was noted as early as day 4 , and was sustained until the end of the study (day 14). Thus aripiprazole may be a potentially effective pharmacological treatment for methamphetamine psychosis. We believe that this may be related to the efficacy of aripiprazole in treating the positive and negative symptoms and depressive and anxiety symptoms. It is not clear why aripiprazole may have a positive effect on symptoms of depression and anxiety. Agents that have an effect on the dopaminergic and serotonergic systems may ameliorate symptoms of depression and anxiety (33). The effects of aripiprazole may arise from its activity at the serotonin 1A (5-HT1A) receptor (34,35), and its partial agonist and dopaminergic stabilising qualities (36).
In our study subjects, treatment with aripiprazole led to a significant decline in AWQ and BSCS scores, indicating a decrease in the severity of the drug withdrawal syndrome and substance cravings. This effect began as early as day 4 , suggesting a rapid onset of action of aripiprazole. This finding is in keeping with results from an earlier study (20) where aripiprazole significantly alleviated cocaine and alcohol cravings in schizophrenia subjects. Therefore, aripiprazole might have a beneficial role in addressing stimulant withdrawal and cravings.

In our study, the initial dose of aripiprazole used was $5-10 \mathrm{mg} \mathrm{mg} / \mathrm{day}$, and was gradually titrated to higher doses of $10 \mathrm{mg} /$ day or $15 \mathrm{mg}$ /day over the study period. The doses used in our patient population appeared to be effective, as reflected in the significant improvements across the efficacy parameters. However, a double-blind study by Newton (37) to evaluate the effects of aripiprazole treatment on abstinence-related craving and cue-induced craving among non-treatment seeking, methamphetamine dependent users, reported that aripiprazole given at $15 \mathrm{mg}$ is unlikely to be efficacious for the treatment of methamphetamine dependence. Whether this discrepancy is purely due to different study designs or could be attributed to genetic reasons (e.g. different ethnicities need different therapeutic doses) remains to be ascertained through further research.

Our study also showed that aripiprazole was well tolerated in most patients and safe to be used in antipsychotic-naive patients, as shown by the low incidence of adverse effects associated with aripiprazole and the high retention rate $(83.6 \%)$ in this study. All the AEs were also of mild to moderate severity. The reported AEs (akathisia, insomnia, agitation, sedation, and depression) were similar to the most common adverse events found in other clinical trials of aripiprazole in 
schizophrenia $(38,39)$. There was a non-significant increase in BARS, mainly due to four patients who reported akathisia. Akathisia is not uncommon with aripiprazole. While second-generation antipsychotic drugs have been reported to cause a lower incidence of extrapyramidal symptoms (EPSs) than typical antipsychotic drugs, AEs such as akathisia have been observed with atypical antipsychotic drugs $(39,40)$.

Currently, the data on efficacy of antipsychotics in methamphetamine induced psychosis are still limited. Only a single small randomised controlled trial (41) involving 58 participants has been published. That study compared the efficacy and tolerability of two antipsychotic drugs, olanzapine and haloperidol, in treating amphetamineinduced psychosis, where both drugs were found to be efficacious. Whether the limited evidence from our current study using aripiprazole can be applied to all methamphetamine dependent psychotic patients in Malaysia is still not known, as the treatment of methamphetamine induced psychosis with aripiprazole needs to be further investigated in larger randomised controlled samples. Further studies of methamphetamine induced psychotic symptoms and the prevalence of relapse of psychosis in the presence of methamphetamine are also crucial to develop study designs appropriate for treatment studies of methamphetamine psychosis.

The limitations of this study were the small sample

\section{References:}

1. United Nations Office of Drugs on Crime (UNODC). World Drug Report 2007. Vienna, Austria, UNODC, 2007.

2. Leduc PA, Mittleman G. Schizophrenia and psychostimulant abuse: a review and re-analysis of clinical evidence. Psychopharmacology (Berl) 1995; 121(4): 407-27.

3. Sato M A lasting vulnerability to psychosis in patients with previous methamphetamine psychosis. Ann N Y Acad Sci 1992; 654: 160-70.

4. McKetin R, McLaren J, Lubman DI, Hides L. The prevalence of psychotic symptoms among methamphetamine users. Addiction 2006; 101(10): 1473-8.

5. Yui K, Goto K, Ikemoto S, Ishiguro T. Stress induced spontaneous recurrence of methamphetamine psychosis: the relation between stressful experiences and sensitivity to stress. Drug Alcohol Depend 2000; 58(1-2): 67-75.

6. Yui K, Goto K, Ishiguro T, Ikemoto S. Noradrenergic activity and spontaneous recurrence of methamphetamine psychosis. Drug Alcohol Depend 1997; 44(2-3): 183-7. size, the open-label design, and the absence of a placebo arm. We attempted to minimize the limitations of the openlabel design by including self-rated scales in addition to the observer-rated scales. In this study, we noted that subjects experienced improvement based on both types of efficacy measurements. Without a placebo arm, the effect of aripiprazole cannot be reliably distinguished from selfabatement after stopping methamphetamines. However, it is worth noting that subjects in this study responded rapidly, as early as day 4 . We assume this rapid response could be due to aripiprazole rather than a natural selflimiting response.

\section{CONCLUSIONS}

This 2-week, open-label study shows that aripiprazole given once-daily at $10 \mathrm{mg} /$ day to $15 \mathrm{mg} /$ day improved the psychotic symptoms associated with methamphetamine use, as measured with PANSS scores. In addition, the treatment also improved depressive and anxiety symptoms, as well as reduced drug withdrawal symptoms and substance craving severity. The treatment was generally well tolerated with mild to moderate AEs comparable to other aripiprazole studies. Aripiprazole may be a potential treatment option for methamphetamine induced psychosis, but its efficacy needs to be confirmed by randomised, larger, and longer-duration studies.

7. Hofmann FG. A handbook on drug and alcohol abuse: the biomedical aspects. 2nd ed., New York, Oxford University Press; 1983.

8. Srisurapanont M, Kittiratanapaiboon P, Jarusuraisin N. Treatment for amphetamine psychosis. Cochrane Database Syst Rev 2001; 4: CD003026.

9. Angrist B, Sathananthan G, Wilk S, Gershon S. Amphetamine psychosis: behavioral and biochemical aspects. J Psychiatr Res 1974; 11: 13-23

10. Richards JR, Derlet RW, Duncan DR. Chemical restraint for the agitated patient in the emergency department: lorazepam versus droperidol. J Emerg Med 1998; 16(4): 567-73.

11. Misra LK, Kofoed L, Oesterheld JR, Richards GA. Olanzapine treatment of methamphetamine psychosis. J Clin Psychopharmacol 2000; 20(3): 393-4.

12. Misra LK, Kofoed L. Risperidone treatment of methamphetamine psychosis. Am J Psychiatry 1997; 154(8): 1170. 
13. Dore G, Sweeting M. Drug-induced psychosis associated with crystalline methamphetamine. Australas Psychiatry 2006; 14(1): $86-9$.

14. Kapur S. How antipsychotics become anti-"psychotic"--from dopamine to salience to psychosis. Trends Pharmacol Sci 2004; 25(8): 402-6.

15. Strange PG. Antipsychotic drugs: importance of dopamine receptors for mechanisms of therapeutic actions and side effects. Pharmacol Rev 2001; 53(1): 119-33.

16. Burris KD, Molski TF, Xu C, Ryan E, Tottori K, Kikuchi T, et al. Aripiprazole, a novel antipsychotic, is a high-affinity partial agonist at human dopamine D2 receptors. J Pharmacol Exp Ther 2002; 302(1): 381-9.

17. Grunder G, Carlsson A, Wong DF. Mechanism of new antipsychotic medications: occupancy is not just antagonism. Arch Gen Psychiatry 2003; 60(10), 974-7.

18. Yokoi F, Grunder G, Biziere K, Stephane M, Dogan AS, Dannals $\mathrm{RF}$, et al. Dopamine D2 and D3 receptor occupancy in normal humans treated with the antipsychotic drug aripiprazole (OPC 14597): a study using positron emission tomography and [11C] raclopride. Neuropsychopharmacology 2002; 27(2): 248-59.

19. Stahl SM. Dopamine system stabilizers, aripiprazole, and the next generation of antipsychotics, part 1, "Goldilocks" actions at dopamine receptors. J Clin Psychiatry 2001; 62(11): 841-2.

20. Beresford T P, Clapp L, Martin B, Wiberg JL, Alfers J, Beresford HF. Aripiprazole in schizophrenia with cocaine dependence: a pilot study. J Clin Psychopharmacol 2005; 25(4): 363-6.

21. Lieberman JA. Dopamine partial agonists: a new class of antipsychotic. CNS Drugs 2004; 18(4): 251-67.

22. Keck PE Jr, Calabrese JR, McIntyre RS, McQuade RD, Carson WH, Eudicone J M, et al. Aripiprazole monotherapy for maintenance therapy in bipolar I disorder: a 100-week, double-blind study versus placebo. J Clin Psychiatry 2007; 68(10): 1480-91.

23. Lopez-Meza E, Ruiz-Chow A, Ramirez-Bermudez J. Aripiprazole in psychosis associated with Parkinson's disease. J Neuropsychiatry Clin Neurosci 2005; 17(3): 421-2.

24. Marcus RN, McQuade RD, Carson WH, Hennicken D, Fava M, Simon JS, et al. The efficacy and safety of aripiprazole as adjunctive therapy in major depressive disorder: a second multicenter, randomized, double-blind, placebo-controlled study. J Clin Psychopharmacol 2008; 28(2): 156-65.

25. Sheehan DV, Lecrubier Y, Sheehan KH, Amorim P, Janavs J, Weiller E, et al. The Mini-International Neuropsychiatric Interview (M.I.N.I.): the development and validation of a structured diagnostic psychiatric interview for DSM-IV and ICD-10. J Clin Psychiatry 1998; 59 (20): 22-33; quiz 34-57.

26. James D, Davies G, Willner P. The development and initial validation of a questionnaire to measure craving for amphetamine. Addiction 2004; 99(9): 1181-8.
27. Somoza E, Baker S, Himmler C, LoCastro J, Mezinskis J, Simon $\mathrm{S}$, et al. The Brief Substance Craving Scale-measuring craving in clinical trials. NIDA Res Monogr 1999; 180: 304-307.

28. Kay SR, Fiszbein A,Opler LA. The positive and negative syndrome scale (PANSS) for schizophrenia. Schizophr Bull 1987; 13(2): 261 76.

29. Rush JA Jr. Abnormal Involuntary Movement Scale (AIMS). in Handbook of Psychiatric Measures, American Psychiatric Association 2000; 166-8.

30. Barnes TR. A rating scale for drug-induced akathisia. $\mathrm{Br} \mathrm{J}$ Psychiatry 1989; 154:672-6.

31. Simpson GM, Angus JW. A rating scale for extrapyramidal side effects. Acta Psychiatr Scand Suppl 1970; 212:11-9.

32. Zigmond AS, Snaith RP. The hospital anxiety and depression scale. Acta Psychiatr Scand 1983, 67(6): 361-70.

33. Stein DJ, Westenberg HG,Liebowitz MR. Social anxiety disorder and generalized anxiety disorder: serotonergic and dopaminergic neurocircuitry. J Clin Psychiatry 2002; 63 Suppl 6: 12-9.

34. Carli M, Tatarczynska E, Cervo L, Samanin R. Stimulation of hippocampal 5-HT1A receptors causes amnesia and anxiolytic-like but not antidepressant-like effects in the rat. Eur J Pharmacol 1993; 234(2-3): 215-21.

35. Collinson N, Dawson GR. On the elevated plus-maze the anxiolytic-like effects of the 5-HT(1A) agonist, 8-OH-DPAT, but not the anxiogenic-like effects of the 5-HT(1A) partial agonist, buspirone, are blocked by the 5-HT1A antagonist, WAY 100635. Psychopharmacology (Berl) 1997; 132(1): 35-43.

36. Adson DE, Kushner MG, Fahnhorst TA. Treatment of residual anxiety symptoms with adjunctive aripiprazole in depressed patients taking selective serotonin reuptake inhibitors. J Affect Disord 2005; 86(1): 99-104.

37. Newton TF, Reid MS, De La Garza R, Mahoney JJ, Abad A, Condos R, et al. Evaluation of subjective effects of aripiprazole and methamphetamine in methamphetamine-dependent volunteers. Int $\mathrm{J}$ Neuropsychopharmacol 2008; 11(8): 1037-45.

38. Kern RS, Green MF, Cornblatt BA, Owen JR, McQuade RD, Carson WH, et al. The neurocognitive effects of aripiprazole: an open-label comparison with olanzapine. Psychopharmacology (Berl) 2006; 187(3): 312-20.

39. Kane JM, Fleischhacker WW, Hansen L, Perlis R, Pikalov A 3rd, Assuncao-Talbott S. Akathisia: an updated review focusing on second-generation antipsychotics. J Clin Psychiatry 2009; 70(5): $627-43$.

40. Iqbal $\mathrm{N}$, Lambert $\mathrm{T}$, Masand $\mathrm{P}$. Akathisia: problem of history or concern of today. CNS Spectr 2007; $12(9-14)$ : 1-13.

41. Leelahanaj T, Kongsakon R, Netrakom P. A 4-week, double-blind comparison of olanzapine with haloperidol in the treatment of amphetamine psychosis. J Med Assoc Thai 2005, 88 (3): 43-52. 